\title{
Kinerja Membran Plat Berpori Berbasis Selulosa Asetat yang Disintesis Secara Inversi Fasa untuk Ultrafiltrasi Bakteri E.coli di PDAM Surabaya
}

\section{Performance of Cellulose Acetate-Based Porous Plate Membranes Synthesized by Phase Inversion for Ultrafiltration of E.coli Bacteria at Surabaya's Water Plant Municipal}

\author{
DHITA ARIYANTI ${ }^{1}$, NURUL WIDIASTUTI ${ }^{2}$, NOURMA SAFARINA ${ }^{3}$ \\ ${ }^{1}$ Sekolah Tinggi Teknologi Nuklir, Badan Tenaga Nuklir Nasional (BATAN) Jalan Babarsari Kotak Pos 6101 YKBB Yogyakarta \\ 55281 Telp. +62-274-484085, 489716 \\ 2Departemen Kimia, Fakultas Sains dan Analitika Data, Kampus ITS Sukolilo, Surabaya 60111 \\ ${ }^{3}$ Unit Pelayanan Terpadu Laboratorium Uji Kualitas Lingkungan, Dinas Lingkungan Hidup Kabupaten Gresik \\ Email: dhita.ariyanti@batan.go.id
}

\begin{abstract}
The lack of consumable water in urban and industrial-dense areas encourages research on clean water treatment methods. Some current treatment methods, such as precipitation, adsorption, and UV light irradiation are ineffective for water with high levels of suspended solids, organic matter, and turbidity. Therefore, alternative approaches are required to support the availability of clean and consumable water. The membrane technology is an alternative filtration method proposed in the East Surabaya's municipal waterworks area. The membrane filtration method is quite simple and easy to operate. This study aimed to determine the performance of cellulose acetate-based porous plate membranes synthesized by phase inversion for E. coli bacteria's ultrafiltration. As a raw material, cellulose acetate is preferred because of its high hydrophilicity and good biocompatibility. Membrane synthesis was carried out through the phase inversion method with acetone solvents and non-solvent water in the coagulation bath. The positive test for E. coli bacteria was carried out through the MPN (Most Probable Number) method on the municipal waterworks water samples before and after filtering with membranes. The results showed that the synthesis of cellulose acetate membrane had good homogeneity. This result was supported by the results of ANOVA single factor statistical data analysis. Also, cellulose acetate membrane had good permeability and flux performance as ultrafiltration of $E$. coli bacteria with a flux of $37.25 \mathrm{~L} / \mathrm{m}^{2}$.hour.bar at a sufficient pressure of 5 bar. Test results for the presence of E. coli bacteria in PDAM water samples using the MPN method gave an initial indication that the water sample after filtration with cellulose acetate membrane was negative.
\end{abstract}

Keywords: membrane, cellulose acetate, permeability, water flux

\begin{abstract}
ABSTRAK
Minimnya air bersih yang layak konsumsi di daerah perkotaan dan padat industri mendorong penelitian tentang metode pengolahan air bersih. Kurangnya efektivitas metode pengolahan sebelumnya seperti pengendapan, adsorbsi, dan penyinaran dengan sinar UV untuk air dengan kadar suspended solids, zat organik, dan kekeruhan yang tinggi, diperlukan metode alternatif untuk mendukung ketersediaan air bersih layak konsumsi. Metode filtrasi alternatif yang ditawarkan di PDAM di kawasan Surabaya Timur. Metode filtrasi dengan membran sangat sederhana dan mudah dalam operasionalnya. Penelitian ini bertujuan untuk mengetahui kinerja membran plat berpori berbasis selulosa asetat yang disintesis secara inversi fasa untuk ultrafiltrasi bakteri E.coli. Selulosa asetat dipilih sebagai bahan baku membran karena selulosa asetat merupakan bahan polimer yang memiliki hidrofilitas tinggi dan biokompatibilitas yang baik. Sintesis membran dilakukan melalui metode inversi fasa dengan pelarut aseton dan nonpelarut air dalam bak koagulasi. Uji positif bakteri E.coli dilakukan melalui metode MPN (Most Probable Number) pada sampel air PDAM sebelum dan sesudah difiltrasi dengan membran. Hasil penelitian menunjukkan bahwa sintesis membran selulosa asetat memiliki homogenitas baik yang ditunjukkan oleh hasil analisis data statistika ANOVA single factor. Selain itu, membran selulosa asetat memiliki kinerja permeabilitas dan fluks yang baik sebagai ultrafiltrasi bakteri E.coli dengan ketercapaian fluks sebesar $37,25 \mathrm{~L} / \mathrm{m}^{2}$.jam.bar pada tekanan efektif sebesar 5 bar. Hasil uji keberadaan bakteri E.coli pada sampel air PDAM dengan metode MPN memberikan indikasi awal bahwa sampel air setelah filtrasi dengan membran selulosa asetat adalah negatif.
\end{abstract}

Kata kunci: membran, selulosa asetat, permeabilitas, fluks air 


\section{PENDAHULUAN}

\subsection{Latar Belakang}

Air bersih merupakan kebutuhan utama bagi seluruh lapisan masyarakat. Ketersediaan air bersih merupakan kepentingan pokok demi terwujudnya kesehatan masyarakat di suatu wilayah. Surabaya Timur adalah salah satu wilayah di Jawa Timur yang berdekatan dengan pesisir pantai. Selain berlokasi di area pesisir, Surabaya Timur juga merupakan wilayah pemukiman padat penduduk yang berdekatan dengan berbagai kawasan industri. Oleh karena itu, ketersediaan air bersih merupakan obyek yang menjadi perhatian khusus di daerah ini. Sebagian ketersediaan air bersih di daerah ini didukung oleh Perusahaan Daerah Air Minum (PDAM) Kota Surabaya. Namun, kualitas air yang disuplai oleh PDAM ini belum berpredikat layak konsumsi bagi masyarakat. Selain karena adanya limbah industri, tingginya populasi penduduk mampu menimbulkan limbah rumah tangga serta adanya kemungkinan intrusi air laut.

Syarat standar air bersih layak minum ada beberapa aspek, di antaranya syarat fisika, kimia, dan biologi. Syarat fisika terdiri dari beberapa aspek seperti kekeruhan skala 5 NTU, tidak berbau, tidak berwarna, rasanya tawar, tidak mengandung padatan terlarut lebih dari $1000 \mathrm{mg} / \mathrm{L}$, dan suhu normal $\left(27^{\circ} \mathrm{C}\right)$. Syarat kimia yang diharuskan meliputi $\mathrm{pH}$ netral, tidak mengandung bahan organik dan anorganik yang berlebihan, dan tingkat kesadahan yang rendah. Terakhir, syarat biologi meliputi ketiadaan mikroorganisme patogen dan nonpatogen. Mikroorganisme patogen yang ada seperti Salmonella typhi, Entoniseba histolyca, dan Infectus hepatitis, sedangkan mikroorganisme nonpatogen di antaranya Coliform bacteria, Actinomycetes, Iron Bacteria, Algae, dan beberapa jenis cacing yang hidup bebas dalam air $^{(1)}$.

Filtrasi atau penyaringan merupakan metode pemisahan material padatan yang terlarut dalam air. Penggunaan media filtrasi atau saringan yang berpori merupakan metode yang terbukti mampu memisahkan padatan tersuspensi halus atau koloida sebanyak mungkin ${ }^{(2)}$. Hasil filtrasi ini disebut juga sebagai primary treatment. Tahap selanjutnya yang biasanya dilakukan setelah filtrasi di antaranya adsorbsi dengan zeolit atau karbon aktif dan desinfeksi menggunakan sinar ultraviolet (UV). Namun, rangkaian teknologi yang digunakan ini masih memiliki beberapa kelemahan seperti sinar UV kurang efektif untuk air dengan kadar suspended solids, zat organik, dan kekeruhan yang tinggi $i^{(1)}$.
Adanya berbagai kekurangan dari metode pengolahan air yang sebelumnya, mendorong para peneliti melakukan riset untuk mencari teknologi alternatif. Membran merupakan salah satu teknologi alternatif yang sedang marak digunakan untuk berbagai problem pemisahan. Membran merupakan lapisan semipermeabel yang berfungsi sebagai filtrasi partikel dengan ukuran molekuler (spesi) dalam suatu larutan. Dengan gaya dorong berupa tekanan, membran dapat dikategorikan sebagai mikro, ultra, dan nanofiltrasi. Padatan tersuspensi dan pelarut dengan berat molekul tinggi tertahan (retentate), sedangkan air dan pelarut dengan berat molekul rendah melewati membran (permeat) ${ }^{(3)}$.

Penelitian ini membahas tentang riset pendahuluan kinerja membran sebagai teknologi pengolahan air minum untuk rejeksi E.coli. Membran yang akan digunakan merupakan membran berbahan dasar polimer dengan ukuran ultrapori antara 1-100 nm. Dengan ukuran pori yang lebih kecil dari ukuran E.coli, maka diharapkan membran polimer mampu merejeksi bakteri sehingga air yang lolos melalui membran memenuhi syarat biologi sebagai air layak minum. E.coli merupakan molekuler utama yang harus dipisahkan dari sistem air karena E.coli adalah kelompok mikroorganisme indikator terkontaminasinya suatu sumber air oleh patogen. Selain itu, densitas E.coli berbanding lurus dengan tingkat pencemaran air. Bakteri koliform ini menghasilkan zat etionin yang dapat menyebabkan kanker dan berbagai racun seperti indol dan skatol yang dapat menimbulkan penyakit bila jumlahnya berlebih di dalam tubuh ${ }^{(4)}$.

Sintesis membran ultrafiltrasi ini berbasis polimer selulosa asetat. Selulosa asetat dipilih karena polimer yang memiliki karakteristik baik seperti harganya yang murah, hidrofilitas dan biokompatibilitas yang baik, serta memiliki nilai fluks yang tinggi(5). Selain itu, selulosa asetat memiliki selektivitas yang baik, termoplastik, mudah larut, dan memiliki warna yang stabil(6,7). Material membran yang beredar di pasar mampu menyaring bakteri dan virus, namun kebanyakan berupa membran komposit film tipis berbahan CTA (cellulose triacetate) yang memiliki toleransi hanya pada $\mathrm{pH}$ rendah dan tidak menghasilkan debit air yang tinggi per satuan inchi persegi. Berdasarkan penelusuran referensi yang telah dilakukan, selulosa asetat banyak digunakan sebagai metode pengolahan air untuk rejeksi logam berat seperti $\mathrm{Cr}$ dan As. Membran ultrafiltrasi dengan modul hollow fiber berbahan dasar polisulfon/selulosa asetat berhasil disintesis untuk menghilangkan arsen dalam air minum. Hasil karakterisasi menunjukkan bahwa membran selulosa asetat 
murni mampu merejeksi As dalam badan air. Rejeksi As meningkat dengan adanya penambahan polisulfon dalam sistem membran hingga $41 \%$ pada permeabilitas 69,6 $\mathrm{L} / \mathrm{m}^{2}$.h.bar ${ }^{(8)}$. Sintesis membran selulosa asetat yang digrafting dengan polivinil klorida (PVC) dengan teknik inversi fasa juga sukses dilakukan untuk rejeksi garam dari air laut menjadi air tawar. Hasil running test selama 36 hari menunjukkan bahwa kinerja membran selulosa asetat/PVC dinyatakan cukup baik di bawah kondisi operasional yang berbeda-beda. Rejeksi garam mencapai $99,985 \%$ setelah dioperasikan selama 20 menit $^{(9)}$.

Studi cross linking membran selulosa asetat juga dilakukan oleh beberapa peneliti. Selulosa asetat yang digrafting dengan $5 \%$ dan $10 \%$ mmol $\mathrm{SiO}_{2}$ membentuk MMM (mixed matrix membrane) mampu meningkatkan kinerja sistem membran dari permeabilitas 32 hingga $82 \mathrm{~kg} / \mathrm{h} / \mathrm{m}^{2} / \mathrm{bar}$ ketika dibandingkan dengan membran selulosa asetat murni untuk rejeksi spesi organik dalam air. Hal ini disebabkan adanya ikatan hidrogen yang kuat antara gugus $\mathrm{Si}-\mathrm{OH}^{(10)}$. Selain silika, grafting membran selulosa asetat juga dilakukan dengan filler graphen oksida (GO) yang menghasilkan antifouling dan efisiensi sangat baik untuk rejeksi molekular organik hingga $91,36 \%{ }^{(11)}$.

Berdasarkan studi literatur yang telah dilakukan, maka penelitian pendahuluan ini dilakukan guna mengetahui kinerja membran berupa permeabilitas dan fluks membran plat berpori berbasis selulosa asetat yang disintesis secara inversi fasa atau imersi presipitasi sebagai ultrafiltrasi bakteri E.coli di kawasan PDAM Surabaya Timur. Hasil dari eksperimen ini dapat digunakan sebagai rujukan penelitian selanjutnya seperti peningkatan kinerja membran selulosa asetat atau eksplorasi metode pengolahan air yang lain.

\subsection{Tujuan Penelitian}

Penelitian ini merupakan penelitian pendahuluan yang bertujuan untuk mengetahui kinerja membran berupa permeabilitas dan fluks membran plat berpori berbasis selulosa asetat yang disintesis secara inversi fasa atau imersi presipitasi sebagai ultrafiltrasi bakteri E.coli di kawasan PDAM Surabaya Timur.

\section{BAHAN DAN METODE}

\subsection{Bahan}

Polimer selulosa asetat dan pelarut aseton yang digunakan berasal dari Sigma Aldrich, sedangkan sampel air PDAM Surabaya Timur diambil di pemukiman Keputih Gang 1, Sukolilo, Surabaya Timur. Penelitian dilakukan di Laboratorium Kimia Fisika, Departemen Kimia,
Fakultas Sains dan Analitika Data, Institut Teknologi Sepuluh Nopember Surabaya.

\subsection{Metode}

Metode pertama yang digunakan dalam penelitian ini adalah pembuatan larutan polimer selulosa asetat. Larutan polimer selulosa asetat $30 \%$ dibuat dengan cara pelarutan bubuk selulosa asetat 30 gram dalam $100 \mathrm{ml}$ aseton pada Erlenmeyer tertutup. Campuran ini kemudian diaduk dengan magnetik stirer selama 24 jam dalam keadaan vakum hingga homogen.

Metode kedua yang dilakukan adalah pencetakan membran dari larutan polimer selulosa asetat. Setelah dicapai homogenitas, larutan selulosa asetat kemudian dicetak. Pencetakan dilakukan dengan cara menuangkan secara perlahan larutan selulosa asetat dalam Erlenmeyer di atas plat kaca. Penuangan larutan dilakukan sepanjang arah $x$, lalu roller digilingkan sepanjang arah $y$, sedemikian sehingga terbentuk lapisan tipis selulosa asetat di atas kaca. Setelah terbentuk lapisan tipis, plat kaca segera dimasukkan ke dalam bak yang berisi air. Dari hasil pencetakan akan terbentuk lapisan bening yang terkelupas dari kaca datar, lapisan bening inilah yang disebut flat membran (Gambar $1 \mathrm{a}$ ).

Metode ketiga yang dilakukan analisis kinerja membran selulosa asetat yang telah disintesis. Analisis kinerja membran dilakukan dengan modul dead-end (modul ultrafiltrasi) untuk mengetahui permeabilitas dan fluks. Penelitian ini menggunakan gaya dorong berupa tekanan. Membran selulosa asetat dimasukkan dalam sel/modul ultrafiltrasi, kemudian dikompaksi dengan cara mengalirkan air PDAM dengan tekanan 3,5 , dan 7 bar menggunakan kompresor (Gambar 1 b). Permeat yang keluar melalui membran ditampung pada gelas ukur, kemudian dicatat waktu yang diperlukan untuk mencapai volume $1 \mathrm{ml}$ (volume air sebagai variabel kontrol).

Metode terakhir adalah uji kualitatif keberadaan bakteri E.coli pada sampel air asli PDAM dan sampel air yang telah dilewatkan melalui membran dengan variasi tekanan yang berbeda, yaitu 5 dan 7 bar dengan metode MPN (Most Probable Number). Pengenceran $10^{1}$ dilakukan dengan cara melarutkan $1 \mathrm{ml}$ sampel ke dalam $9 \mathrm{ml}$ larutan pengencer LB (Lactose Broth). Pada setiap pengenceran dilakukan pengocokan minimal 25 kali, kemudian dipindahkan dengan menggunakan pipet steril, sebanyak $1 \mathrm{ml}$ larutan dari setiap pengenceran ke dalam 3 seri tabung Lactose Broth (LB) yang berisi tabung durham. Semua alat dan bahan yang diperlukan diautoklaf pada suhu $120^{\circ} \mathrm{C}$ selama \pm 1 jam dengan tujuan sterilisasi alat dan bahan agar terbebas dari bakteri ataupun 
mikroorganisme lain (12). Merk autoklaf yang digunakan dalam penelitian ini adalah elektrik YX-24LM nontimer 24 Liter stainless steel GEA. Penelitian ini menggunakan pengenceran duplo untuk setiap tabung. Tabung-tabung tersebut diinkubasi selama 24 jam pada suhu $35{ }^{\circ} \mathrm{C}$.
Tabung positif ditandai dengan kekeruhan, endapan, dan gas dalam tabung durham. Jika hasil positif, maka dikatakan air positif mengandung E.coli. Tabung positif ditandai dengan larutan berwarna keruh dan timbul endapan dalam tabung Durham.

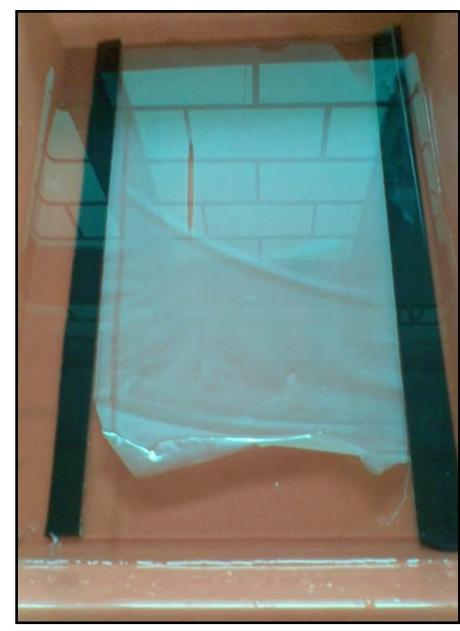

(a)

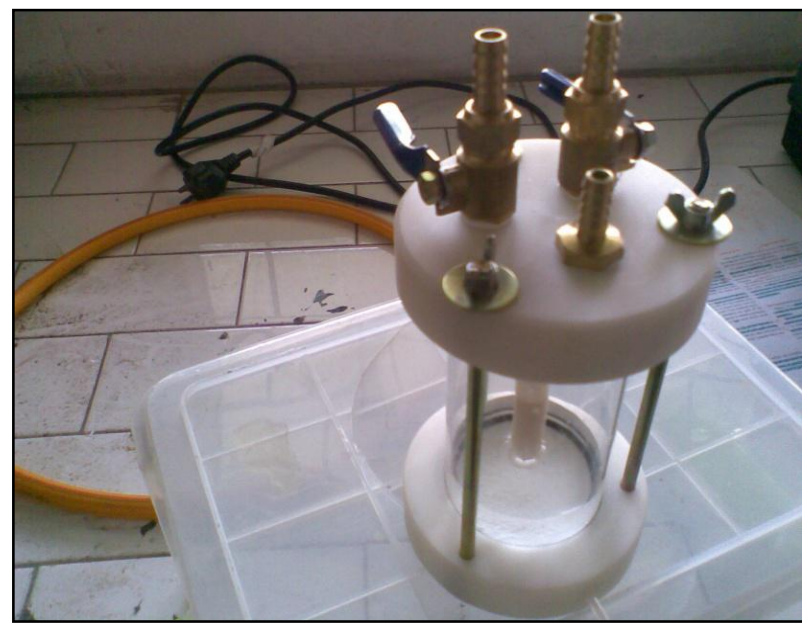

(b)

Gambar 1. Proses sintesis membran selulosa asetat dengan metode inversi fasa. a) Pencetakan membran selulosa asetat, b) Modul dead-end untuk analisis kinerja membran selulosa asetat berupa permeabilitas dan fluks

\section{HASIL DAN PEMBAHASAN}

\subsection{Analisis permeabilitas membran selulosa asetat dan fluks sampel air pada tekanan yang berbeda-beda}

Permeabilitas membran selulosa asetat merupakan ukuran kecepatan dari suatu spesi melewati membran. Secara kuantitas, permeabilitas membran sering dinyatakan sebagai fluks atau koefisien permeabilitas. Fluks sendiri didefinisikan sebagai banyaknya spesi yang dapat menembus membran tiap satuan luas membran per satuan tekanan(13). Fluks ini bergantung pada jumlah pori pada membran selulosa asetat. Analisis fluks juga dilakukan menggunakan modul ultrafiltrasi dead-end. Hasil penelitian nilai permeabilitas membran selulosa asetat dan fluks air PDAM yang melalui membran selulosa asetat ditunjukkan oleh Tabel 1 serta ditampilkan pada Gambar 2 dan 3.

Air sampel PDAM dapat melewati membran karena adanya porositas dalam membran selulosa asetat. Porositas terbentuk karena adanya pertukaran molekul-molekul pelarut berupa aseton dan molekul nonpelarut berupa air dalam bak koagulasi. Pertukaran molekulmolekul ini meninggalkan ruang-ruang kosong (cavity) dalam sistem lapisan membran.
Fenomena pertukaran molekul antar pelarut dan nonpelarut disebut dengan inversion phase atau rendam endap ${ }^{(14)}$.

Tabel 1 yang diplotkan pada Gambar 2 merupakan permeabilitas atau kemampuan $1 \mathrm{ml}$ sampel air PDAM melewati membran selulosa asetat. Sedangkan Gambar 3 menyatakan fluks $1 \mathrm{ml}$ sampel air PDAM yang melalui membran selulosa asetat per satuan luas membran, waktu, dan tekanan. Dalam penelitian ini driving force yang digunakan adalah tekanan, sehingga variabel independen yang dipakai adalah tekanan yang divariasikan. Hasil penelitian menunjukkan bahwa pada tekanan 7 bar, permeabilitas dan fluks air yang mengalir melalui membran selulosa asetat semakin rendah. Berdasarkan telaah literatur, hal ini disebabkan adanya fouling atau penyumbatan. Meskipun membran selulosa asetat merupakan membran yang memiliki hidrofilitas tinggi dan resistan terhadap fouling, namun faktanya ketika membran dikompaksi dengan tekanan yang tinggi fouling akan tetap terjadi $(15,16)$. Penyumbatan ini terjadi akibat terjerapnya spesi-spesi yang ada dalam sampel air di dalam pori-pori membran. Hal ini menjadi penyebab dari rendahnya permeabilitas dan fluks air yang melewati membran selulosa asetat pada tekanan yang tinggi. 
Tabel 1. Permeabilitas membran selulosa asetat dan fluks air PDAM melalui membran hasil eskperimen

\begin{tabular}{|c|c|c|c|c|c|c|}
\hline \multirow{2}{*}{ No. } & \multicolumn{3}{|c|}{ Permeabilitas Membran Selulosa Asetat (I/m².jam) } & \multicolumn{3}{|c|}{ Fluks Air PDAM (I/m².jam.bar) } \\
\hline & 3 bar & 5 bar & 7 bar & 3 bar & 5 bar & 7 bar \\
\hline \multicolumn{4}{|c|}{${ }^{*}$ Data kontrol (pada tekanan 0 bar) $=0$} & \multicolumn{3}{|c|}{ Data kontrol (pada tekanan 0 bar $)=0$} \\
\hline 1. & 0,0035 & 0,0019 & 0,0017 & 33.70 & 37.25 & 29.73 \\
\hline 2. & 0,0043 & 0,0024 & 0,0015 & 27.43 & 29.49 & 32.61 \\
\hline 3. & 0,0045 & 0,0023 & 0,0022 & 26.21 & 30.77 & 22.98 \\
\hline 4. & 0,0048 & 0,0027 & 0,0024 & 24.55 & 26.31 & 21.06 \\
\hline 5. & 0,0047 & 0,0029 & 0,0027 & 25.15 & 24.74 & 18.72 \\
\hline 6. & 0,0046 & 0,0027 & 0,0027 & 25.75 & 25.73 & 18.38 \\
\hline 7. & 0,0047 & 0,0027 & 0,0028 & 25.15 & 25.73 & 18.05 \\
\hline 8. & 0,0061 & 0,0029 & 0,0028 & 19.22 & 24.32 & 17.73 \\
\hline 9. & 0,0067 & 0,0030 & 0,0029 & 17.63 & 22.97 & 17.43 \\
\hline 10. & 0,0069 & 0,0035 & 0,0031 & 17.09 & 20.39 & 16.41 \\
\hline
\end{tabular}

*Data kontrol dilakukan pada 0 bar karena driving force berupa tekanan dijadikan sebagai variabel manipulatif

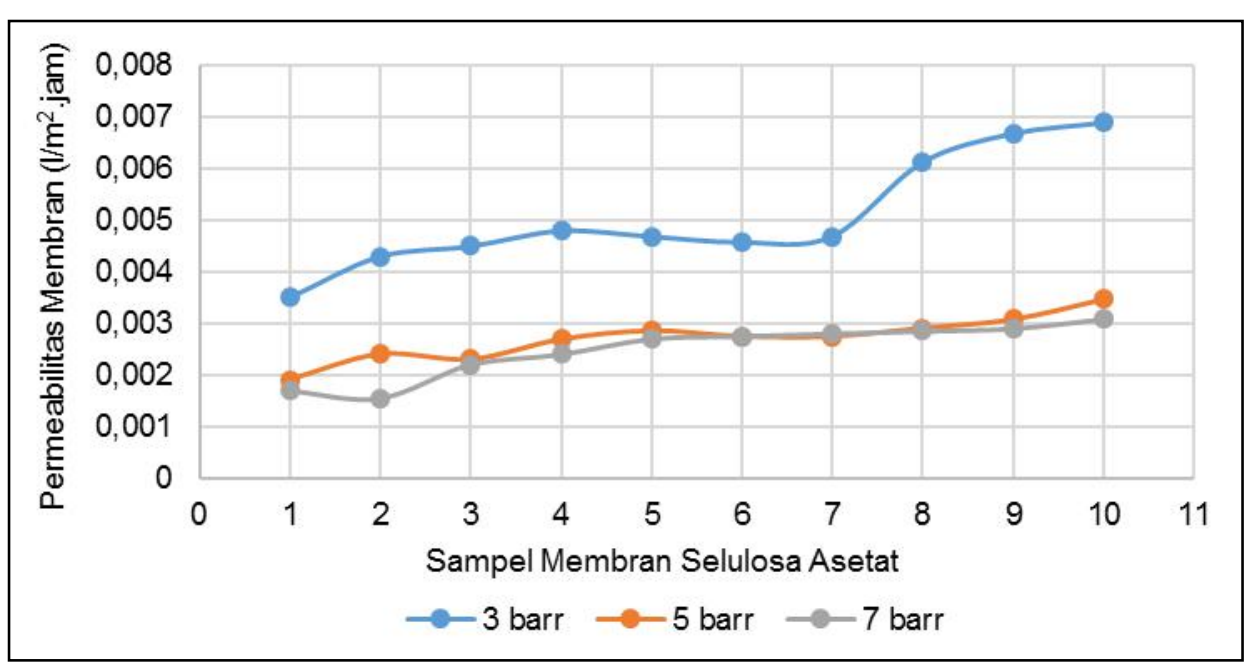

Gambar 2. Grafik pengaruh tekanan terhadap permeabilitas membran selulosa asetat

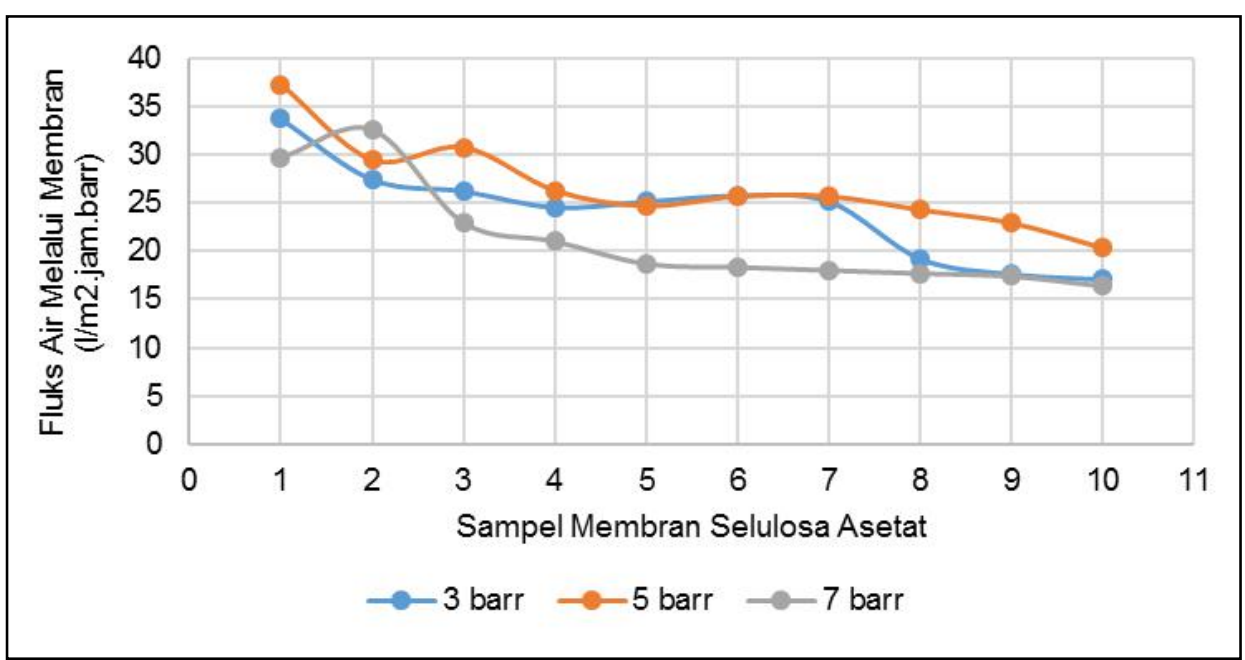

Gambar 3. Grafik pengaruh tekanan terhadap fluks air yang melewati membran selulosa asetat

Fouling atau penyumbatan ini dapat diantisipasi dengan beberapa metode. Pertama, treatment atau pengkondisian sampel air yang akan difiltrasi dengan membran selulosa asetat 
seperti penambahan kation $\mathrm{Ca}^{2+}$, pengubahan nilai $\mathrm{pH}$, penambahan koagulan, zat oksidan seperti ozon dan permanganat, serta penambahan adsorben seperti PAC (powder activated carbon). Kedua, pengkondisian sifat membran itu sendiri yang dapat dilakukan dengan mengubah ukuran pori, hidrofilitas/hidrofobisitas, muatan, dan peningkatan kondisi hidrodinamik(17).

Berdasarkan data analisis yang diperoleh dalam penelitian, fluks sampel air PDAM yang melewati membran selulosa asetat secara kumulatif dikatakan tidak berbeda secara signifikan pada tekanan yang bervariasi (Gambar 4). Hal ini dapat menjadi pertimbangan bahwa dengan tekanan 5 bar, membran selulosa asetat sudah dapat melakukan filtrasi sampel air PDAM secara efektif dengan nilai fluks mencapai $37,25 \mathrm{l} / \mathrm{m}^{2}$.jam.bar. Nilai fluks pada penelitian ini lebih rendah dibandingkan dengan nilai fluks membran selulosa asetat yang disintesis untuk rejeksi logam As yaitu 79,1 $1 / \mathrm{m}^{2}$.jam ${ }^{(18)}$ tetapi lebih tinggi dari nilai fluks air yang melewati membran nanokristal selulosa $7,21 \mathrm{l} / \mathrm{m}^{2}$.jam ${ }^{(16)}$. Hal ini disebabkan oleh perbedaan pelarut polimer selulosa asetat saat sintesis dan perbedaan kondisi operasional. Dalam penelitian terdahulu tersebut, filtrasi dilakukan pada suasana asam $(\mathrm{pH} 4)$ dengan menggunakan pelarut NMP (N-methyl-2pyrrolidone $)^{(16)}$. Perbedaan kondisi operasional dan pemilihan pelarut yang digunakan untuk sintesis membran selulosa asetat dapat menyebabkan perbedaan porositas dan nilai fluks. Penelitian tentang kinerja membran selulosa asetat untuk rejeksi pewarna juga pernah dilakukan dan menghasilkan nilai fluks air mencapai $100 \mathrm{l} / \mathrm{m}^{2}$.jam.bar ${ }^{(15)}$. Tingginya nilai fluks tersebut dikarenakan penggunaan pelarut yang berbeda. Dalam penelitian tersebut, membran selulosa asetat disintesis dengan pelarut 1-ethyl-3-methylimidazolium asetat ([EMIM]OAc dan nonpelarut etanol. Perbedaan jenis pelarut yang digunakan berdampak secara signifikan terhadap ukuran pori membran. Hal ini disebabkan karena nilai viskositas pelarut yang berbeda beda, sehingga mempengaruhi kecepatan transisi molekul pelarut dan nonpelarut dalam sistem membran $(19,20)$.

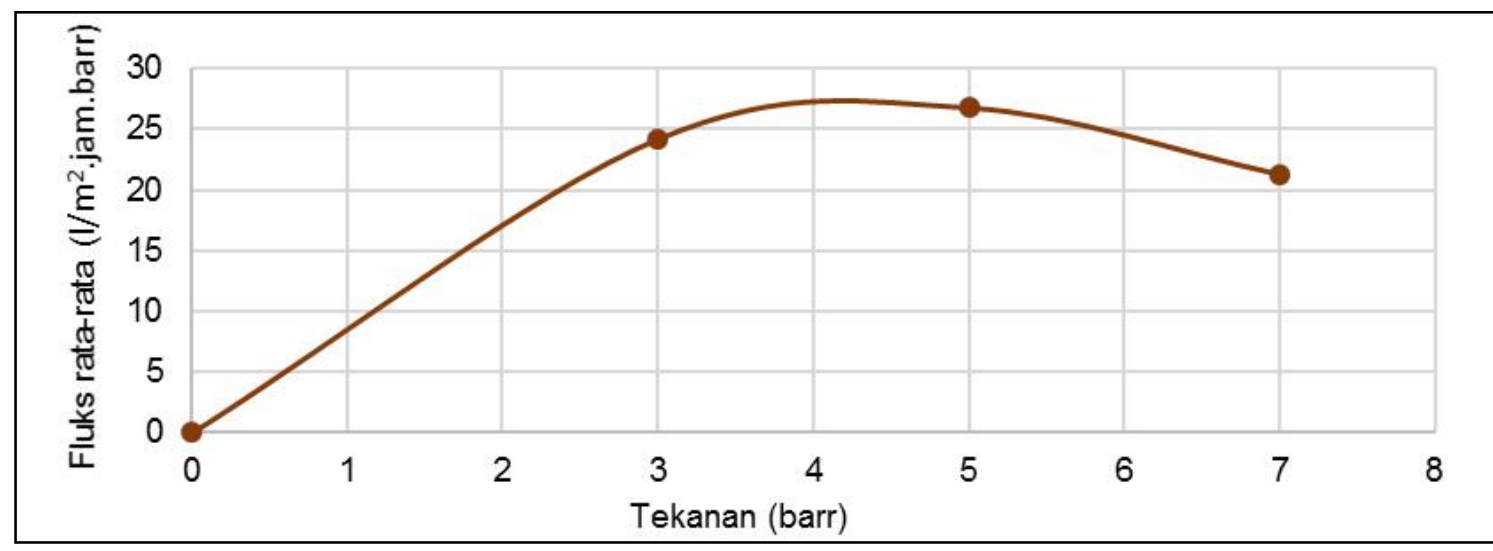

Gambar 4. Grafik kumulatif pengaruh tekanan terhadap fluks air rata-rata yang melewati membran selulosa asetat

Sejalan dengan penelitian yang dilakukan oleh beberapa peneliti sebelumnya, sintesis membran selulosa asetat dilakukan dengan pelarut DMAc dan air deionisasi sebagai nonpelarut menghasilkan fluks air sebesar 11,4 $\mathrm{I} / \mathrm{m}^{2}$.jam.bar. Namun, ketika peningkatan kinerja membran dilakukan dengan cara penambahan aditif lain seperti halloysite nanotubes (HNTs), kinerja fluks air pada membran selulosa asetat tersebut meningkat menjadi $92,9 \mathrm{l} / \mathrm{m}^{2}$.jam.bar(21).

Berdasarkan uji statistika dengan metode ANOVA single factor pada Tabel 2, dapat diketahui bahwa hasil sintesis membran selulosa asetat dari polimer selulosa asetat berpelarut aseton dikatakan homogen. Homogenitas hasil sintesis membran selulosa asetat ini dapat dilihat dari perbandingan nilai $f_{\text {hitung }}$ dan $f_{\text {critical }}$ fluks sampel air yang terjadi pada kesepuluh membran selulosa asetat yang telah

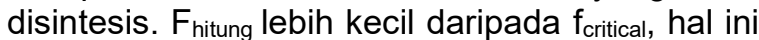
menunjukkan bahwa kesepuluh sampel membran selulosa asetat yang telah disintesis adalah homogen atau tidak memiliki kinerja yang berbeda-beda. Dengan tingkat kepercayaan $95 \%$, homogenitas membran hasil sintesis dapat juga diindikasikan dari uji statistika berupa pvalue. Hasil $p_{\text {value adalah }}$ 0,07557 yang lebih besar dari 0,05 (5\% kesalahan), ini artinya dari kesepuluh membran selulosa asetat hasil sintesis adalah homogen atau tidak memiliki perbedaan kinerja yang signifikan. 
Tabel 2. Hasil uji statistika dengan metode ANOVA single factor sintesis membran selulosa asetat SUMMARY

\begin{tabular}{ccccc}
\hline Groups & Count & Sum & Average & Variance \\
\hline 3 bar & 10 & 241,88 & 24,188 & 25,28544 \\
5 bar & 10 & 267,7 & 26,77 & 22,31904 \\
7 bar & 10 & 213,1 & 21,31 & 31,02658 \\
\hline
\end{tabular}

ANOVA

\begin{tabular}{lcrcccc}
\hline \multicolumn{1}{c}{ Source of Variation } & SS & $d f$ & $M S$ & $F$ & P-value & F crit \\
\hline Between Groups & 149,204 & 2 & 74,60201 & 2,84628 & 0,07557 & 3,354131 \\
Within Groups & 707,6796 & 27 & 26,21035 & & & \\
Total & 856,8836 & 29 & & & & \\
\hline
\end{tabular}

\subsection{Analisis kualitatif keberadaan E.coli pada sampel PDAM setelah ultrafiltrasi dengan membran selulosa asetat}

Berdasarkan analisis kualitatif uji keberadaan bakteri E.coli dengan metoda MPN (Most Probable Number), dapat diketahui bahwa sampel air PDAM menghasilkan tabung positif yang ditandai dengan larutan berwarna keruh,

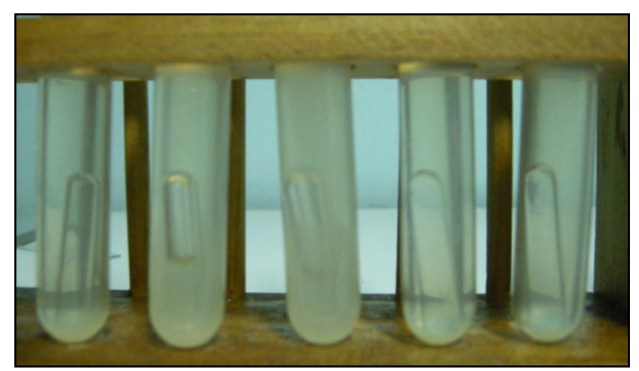

(a) timbul endapan, dan terbentuk gas dalam tabung Durham (Gambar 5. a). Sampel air PDAM yang telah melalui filtrasi dengan membran selulosa asetat menunjukkan hasil tabung Durham jernih dan tidak timbul endapan (Gambar 5. b). Hal ini merupakan indikasi awal bahwa bakteri E.coli telah terfilter dari sampel air PDAM dan tertahan di permukaan membran selulosa asetat sebagai retentat.

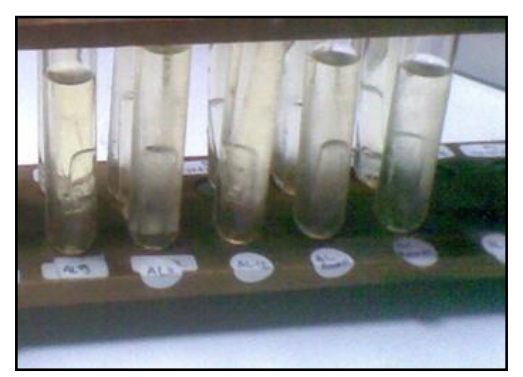

(b)

Gambar 5. Hasil uji kualitatif bakteri E.coli dengan metode MPN pada sampel air PDAM. a) Sebelum difiltrasi dengan membran selulosa asetat (kontrol air PDAM terhadap keberadaan bakteri E.coli) b) Setelah melalui proses filtrasi dengan membran selulosa asetat

\section{KESIMPULAN}

Berdasarkan hasil penelitian, dapat disimpulkan bahwa membran plat berpori berbasis selulosa asetat berhasil disintesis secara inversi fasa atau imersi presipitasi dengan homogenitas baik yang ditunjukkan oleh perhitungan data statistika berupa metode ANOVA single factor. Membran selulosa asetat hasil sintesis ini memiliki kinerja permeabilitas dan fluks yang baik sebagai ultrafiltrasi bakteri E.coli di kawasan PDAM Surabaya Timur dengan ketercapaian fluks sebesar 37,25 $\mathrm{L} / \mathrm{m}^{2}$.jam. bar pada tekanan efektif sebesar 5 bar. Hasil uji kualitatif keberadaan bakteri E.coli pada sampel air PDAM dengan metode MPN memberikan indikasi awal bahwa sampel air setelah filtrasi dengan membran selulosa asetat adalah negatif. 


\section{PERSANTUNAN}

Penulis mengucapkan terima kasih kepada Unit Penelitian dan Pengabdian Masyarakat Sekolah Tinggi Teknologi Nuklir Badan Tenaga Nuklir Nasional (STTN-BATAN) Yogyakarta dan Laboratorium Kimia Fisika Departemen Kimia, Fakultas Sains dan Analitika Data, Kampus ITS Surabaya atas dukungan sarana dan prasarana yang diberikan sehingga penelitian ini berjalan lancar.

\section{DAFTAR PUSTAKA}

1. Wiyono, N., Faturrahman, A., \& Syauqiah, I. (2017). Sistem Pengolahan Air Minum Sederhana (Portable Water Treatment). Konversi, 27-35.

2. Quddus, R. (2014). Teknik Pengolahan Air Bersih dengan Sistem Saringan Pasir Lambat (Downflow) yang Bersumber dari Sungai Musi. Jurnal Teknik Sipil dan Lingkungan Volume 2 Nomor 4, 669-675.

3. Wenten, Khoiruddin, Aryanti, \& Hakim. (2000). Pengantar Teknologi Membran. Bandung: Diktat Teknik Kimia ITB.

4. Adrianto, R. (2018). Pemantauan Jumlah Bakteri Coliform Di Perairan Sungai Provinsi Lampung. Majalah Teknologi Agro Industri (Tegi) Volume 10 Nomor 1, 1-6.

5. Vinodhini, A., Sangeetha, Gomathi, T., Sudha, Venkatesan, J., \& Anil, S. (2017). FTIR, XRD and DSC studies of nanochitosan, cellulose acetate and polyethylene glycol blend ultrafiltration membranes. International Journal of Biological Macromolecules 104, 1721-1729.

6. Indriyani, V., Novianty, Y., \& Mirwan, A. (2017). Pembuatan Membran Ultrafiltrasi dari Polimer Selulosa Asetat dengan Metode Inversi Fasa. Konversi Volume 6 Nomor 1, 1116.

7. Gebru, K. A., \& Das, C. (2018). Humic acid removal using cellulose acetate membranes grafted with poly (methyl methacrylate) and aminated using tetraethylenepentamine. Journal of Environmental Management 217, 600-610.

8. Kumar, M., Isloor, A. M., Rao, S., \& Ibrahim, S. (2019). Fabrication of polyphenylsulfone/cellulose acetate and polyphenylsulfone/cellulose acetate phthalate ultrafiltration hollow fiber membranes for the removal of arsenic from drinking water. International Journal of Biological Macromolecules https://doi.org/10.1016/, 1-37.
9. El-Gendi, A., Abdallah, H., Amin, A., \& Amin, S. K. (2017). Investigation of polyvinylchloride and cellulose acetate blend membranes for desalination. Journal of Molecular Structure $1146,14-22$.

10. Mendes, G., Faria, M., Carvalho, A., Gonc,alves, M. C., \& Pinho, M. N. (2018). Structure of water in hybrid cellulose acetatesilica ultrafiltration membranes and permeation properties. Carbohydrate Polymer https://doi.org/10.1016/j.carbpol.2018.02.030 , 1-34.

11.Yang, S., Zou, Q., Wang, T., \& Zhang, L. (2019). Effects of GO and MOF@GO on the permeation and antifouling properties of cellulose acetate ultrafiltration membrane. Journal of Membrane Science 569, 48-59.

12. Nurrobifahmi, Iswandi, A., Yadi, S., Ishak. (2017). Pengaruh Metode Sterilisasi Radiasi Sinar Gamma Co-60 dan Autoklaf terhadap Bahan Pembawa, Viabilitas Spora Gigaspora margarita dan Ketersediaan Fe, Mn, dan Zn. Jurnal Tanah dan Iklim Vol. 41 No. 1, 1-8.

13. Arthanareeswaran, Thanikaivelan, Jaya, N., Mohana, D., \& Raajenthiren, M. (2007). Removal of chromium from aqueous solution using cellulose acetate and sulfonated poly(ether ether ketone) blend ultrafiltration membranes. Journal of Hazardous Materials B139, 44-49.

14.Sun, Z., \& Chen, F. (2016). Hydrophilicity and antifouling property of membrane materials fromcellulose acetate/polyethersulfone in DMAc. International Journal of Biological Macromolecules 91, 143-150.

15.Lee, J. S., Heo, S. A., Jo, H. J., \& Min, B. R. (2016). Preparation and characteristics of cross-linked cellulose acetate ultrafiltration membranes with high chemical resistance and mechanical strength. Reactive and Functional Polymers 99, 114-121.

16.Lv, J., Zhang, G., Zhang, H., \& Yang, F. (2017). Exploration of permeability and antifouling performance on modifiedcellulose acetate ultrafiltration membrane with cellulose nanocrystals. Carbohydrate Polymers 174, 190-199.

17.Zhang, Y., \& Fu, Q. (2018). Algal fouling of microfiltration and ultrafiltration membranes and control strategies: A review. Separation and Purification Technology 203, 193-208.

18. Jayalakshmi, Rajesh, Senthilkumar, Sankar, H., \& Mohan. (2014). Preparation of poly (isophthalamide-graft-methacrylamide) and its utilization in the modification of cellulose acetate ultrafiltration membranes. Journal of 
Industrial and Engineering Chemistry 20, 133 144.

19.Durmaz, E. N., \& Çulfaz-Emecen, Z. (2018) Cellulose-based membranes via phase inversion using [EMIM]OAc-DMSO mixtures as solvent. Chemical Engineering Science 178, 93-103.

20.Gebru, K. A., \& Das, C. (2017). Effects of solubility parameter differences among PEG, PVP and CA on the preparation of ultrafiltration membranes: Impacts of solvents and additives on morphology, permeability and fouling performances. Chinese Journal of Chemical Engineering 25, 911-923.

21.Mu, K., Zhang, D., Shao, Z., Qin, D., Wang, Y., \& Wang, S. (2017). Enhanced permeability and antifouling performance of cellulose acetate ultrafiltration membrane assisted by IDOPA functionalized halloysite nanotubes. Carbohydrate Polymers 174, 688-696. 